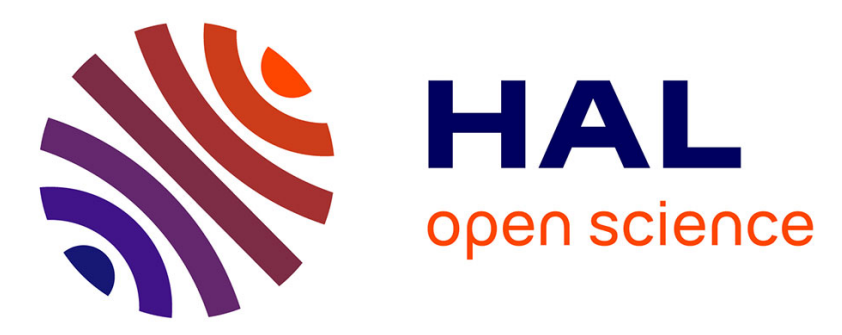

\title{
Electrical conductivity of magma in the course of crystallization controlled by their residual liquid composition.
}

Fabrice Gaillard, Giada Iacono-Marziano

\section{- To cite this version:}

Fabrice Gaillard, Giada Iacono-Marziano. Electrical conductivity of magma in the course of crystallization controlled by their residual liquid composition.. Journal of Geophysical Research, 2005, 110, pp.B06204. 10.1029/2004JB003282 . hal-00023414

HAL Id: hal-00023414

https://hal-insu.archives-ouvertes.fr/hal-00023414

Submitted on 17 Dec 2010

HAL is a multi-disciplinary open access archive for the deposit and dissemination of scientific research documents, whether they are published or not. The documents may come from teaching and research institutions in France or abroad, or from public or private research centers.
L'archive ouverte pluridisciplinaire HAL, est destinée au dépôt et à la diffusion de documents scientifiques de niveau recherche, publiés ou non, émanant des établissements d'enseignement et de recherche français ou étrangers, des laboratoires publics ou privés. 


\title{
Electrical conductivity of magma in the course of crystallization controlled by their residual liquid composition
}

\author{
F. Gaillard ${ }^{1}$ \\ Bayerisches Geoinstitut, Universität Bayreuth, Bayreuth, Germany \\ G. Iacono Marziano \\ Dipartimento di Chimica e Fisica della Terra, Università degli Studi di Palermo, Palermo, Italy \\ Received 30 June 2004; revised 28 February 2005; accepted 14 March 2005; published 29 June 2005.
}

[1] The electrical conductivity of a magma in the course of crystallization was experimentally investigated in the temperature range of $1350-1018^{\circ} \mathrm{C}$. Large samples of basaltic composition with a homogeneous crystal content were synthesized in a gas mixing furnace at $1 \mathrm{~atm}$ pressure. The samples were analyzed by electron microprobe. The relative proportions of the phases as a function of temperature were determined. Depending on temperature, the phase assemblies included quenched silicate liquid, \pm plagioclase, \pm pyroxene, $\pm \mathrm{Fe}$-Ti oxides. The crystal content varied from 0 to $80 \mathrm{wt} \%$. In response to partial crystallization, the residual liquid changed composition from basalt, to andesite, to dacite liquid. The electrical conductivity of the partially crystallized basaltic samples was measured. In addition, above liquidus conductivity measurements were conducted on compositions matching the residual liquid at different temperature. These supplemental electrical measurements allowed us to discriminate the effect of crystal content from the effect of changing liquid composition associated with partial crystallization. Combining with the modified Archie's law a set of constraints describing the conductivity of the residual liquid versus chemical composition and temperature, we propose an equation to calculate changes in conductivity associated with partial magma crystallization. We showed how the composition of the residual liquid is critical on the electrical behavior of crystal-liquid system. The model overcomes the previous difficulties in finding a robust model for describing the electrical behavior of crystal-liquid systems. The effect of liquid composition on the electrical conductivity is related to diffusion mechanisms and transport properties in molten silicate. Combining known constraints on $\mathrm{Na}$ tracer diffusion and our conductivity results confirms the statements that sodium is the dominant charge carrier silicate liquids from basalt to rhyolite. These findings revealed that we need a comprehensive model that can predict the conductivity of molten silicate as a function of chemical composition.

Citation: Gaillard, F., and G. I. Marziano (2005), Electrical conductivity of magma in the course of crystallization controlled by their residual liquid composition, J. Geophys. Res., 110, B06204, doi:10.1029/2004JB003282.

\section{Introduction}

[2] Magnetotelluric surveys have revealed many regions within the Earth's interior with anomalously high electrical conductivity. These regions are often attributed on the basis of independent geological and experimental constraints to the presence of magmas [Pous et al., 1999; Hoffmann-Rothe et al., 2001; Schilling and Partzsch, 2001; Brasse et al., 2002; Park and Ducea, 2003]. The electrical signature of these magmatic reservoirs, determined at surface, could be used to infer the maturity reached by the magma, at depth,

\footnotetext{
${ }^{1}$ Also at UMR 6113 CNRS, CNRS, Orleans, France.
}

in terms of volatile abundances, temperature and crystal content given that appropriate laboratory studies are available. Most of terrestrial magmas are composed of silicate liquid plus a crystal fraction ranging from 0 to $80 \%$. Previous work revealed the electrical conductivity of crystals to be in the range of $10^{-10}-10^{-3}(\mathrm{ohm} \mathrm{m})^{-1}$ [Huebner and Dillenburg, 1995], whereas the conductivity of silicate liquids was shown to vary within a range of $10^{-2}-10$ (ohm $\mathrm{m})^{-1}$ [Waff and Weill, 1975; Tyburczy and Waff, 1983, 1985; Gaillard, 2004]. Therefore the liquid phase is the dominant conductor; the solid crystals can be regarded as insulators. The question will be to elucidate the extent of conductivity decrease associated with partial magma crystallization. Several theoretical models predict the change in conductivity in a system of two phases as a function of the relative proportions of each component [Hashin and Shtrikman, 
1962; Waff, 1974; Glover et al., 2000a, and references therein]. These models generally assume a simplified geometry with insulating materials that are spheres or cubes embedded in a liquid and conductive matrix [Partzsch et al., 2000]. For successful utilization of magnetotelluric measurements as a remote probe of the status or the maturity reached by the magma at depth, a robust method for calculating the effect of crystal content on the bulk electrical conductivity of a magma is required. The experimental approach, which allows magma crystallization to be performed under controlled thermodynamic conditions and the associated changes in electrical conductivity to be measured, offers a pragmatic way to verify the applicability of these theoretical predictions.

[3] Here, we present new experimental data showing that the changes in conductivity associated with partial crystallization of basalt can be successfully adjusted using a theoretical law in the crystal range $0-80 \%$. Furthermore, we show that the most spectacular effect of partial crystallization is the associated chemical change in the residual liquid compositions that dramatically affect electrical conductivity. It appears therefore that we need more data to model the conductivity of molten silicates as a function of the chemical composition.

\section{Background}

[4] Electrical conductivity of crystals is generally well described using an Arrhenius equation that has the following form:

$$
\sigma=\sigma_{0} \exp (-\mathrm{Ea} / \mathrm{RT})
$$

where $\sigma_{0}$ and Ea are adjustable parameters revealing the nature of the charge carrier, its concentration, mobility, and temperature dependence [Tyburczy and Fisler, 1995]. Depending on the temperature, the nature and mobility of charge carriers and their chemical environment the electrical conductivity of crystals can greatly vary. Typical values fall in the range $10^{-10}-10^{-3}$ (ohm m) ${ }^{-1}$ [Huebner and Dillenburg, 1995; Constable et al., 1992].

[5] The conductivity of molten silicate cannot in theory be reproduced using an Arrhenius equation because of the configurational entropy term [Richet, 1984]. Basically, a plot of the logarithm of electrical versus reciprocal temperature is not linear in the temperature range of $900-1700^{\circ} \mathrm{C}$ [Mungall, 2002]. In practice, if one looks at the temperature range restricted to the conditions encountered in natural magmas (i.e., $800-1300^{\circ} \mathrm{C}$ ), the temperature dependence of electrical conductivity of molten silicate can be described by an Arrhenius approximation. Values of electrical conductivity of magmatic silicate melts range from $10^{-3}$ to $10(\mathrm{ohm} \mathrm{m})^{-1}$ depending on temperature and composition [Waff and Weill, 1975; Tyburczy and Waff, 1983; Gaillard, 2004]. Using the Nernst-Einstein equation, these changes in melt electrical properties were attributed to variations in the mobility of sodium that is the main charge carrier in response to changes in the melt chemical composition [Gaillard, 2004].

[6] Except for the recent study of Scarlato et al. [2004], most previous work addressed the electrical behavior of partially molten rock with $0-30 \%$ silicate liquid [Presnall et al., 1972; Roberts and Tyburczy, 1999; Partzsch et al., 2000]. The efforts were conducted to detect the threshold of liquid content required to pass from a melt distributed as an insulated pocket in a solid matrix to an interconnected melt. Different theoretical and empirical formalisms were applied to reproduce the observed electrical behavior. Partzsch et al. [2000] adopted a solution with the conductivity of the liquid obeying an Arrhenius law and fitted their data with the modified "bricklayer" model [Schilling et al., 1997]. However, incomplete attainment of textural equilibrium was invoked by Partzsch et al. [2000] to explain the measured deviation from the modified "bricklayer" model at a low melt fraction. Because of the extremely sluggish kinetics of melt migration within solid grains at low melt fraction (low temperature), a significant part of this melt remained insulated in pockets and contributing only weakly to the bulk electrical behavior of the rock. Roberts and Tyburczy [1999] apparently did not encounter this experimental problem and they adopted an Archie's law coupled with a constant, but adjustable, electrical conductivity for the liquid regardless of temperature. As pointed out by Roberts and Tyburczy, the changes in melt fraction result in changes in the melt composition that in turn should modify its electrical conductivity. However, because neither changes in the melts chemical composition nor proportion were strictly measured, the work of Roberts and Tyburczy [1999] cannot offer a comprehensive clarification of electrical properties in crystal-liquid systems. In fact, these correlated changes in liquid fraction and composition are probably responsible for the difficulties in finding a convincing solution for describing the electrical behavior of partially molten and partially crystallized systems.

[7] Recently, the electrical behavior of a basaltic lava and mafic cumulates compositions from Mount Etna was measured at high pressure by Scarlato et al. [2004]. Scarlato et al. synthesized first partially crystallized samples at variable temperature, and second, they measured conductivity at temperatures low enough to avoid any changes in the supercooled melt/crystal ratio. The crystal content of their samples ranged from 92 to $20 \mathrm{vol} \%$, which induced a change in the residual liquid composition from basalt to andesite. Despite these chemical changes, Scarlato et al. [2004] demonstrated that the Hashin-Strikman upper bound [Hashin and Shtrikman, 1962] can satisfactorily fit their low-temperature data. They showed that increasing the fraction of glass increases the conductivity in a way similar to what is predicted by the Hashin-Strikman upper bound. However, this was demonstrated considering a single value of glass conductivity, which was independent of changes in composition and at a single temperature of $700^{\circ} \mathrm{C}$. In addition, most of the data of Scarlato et al. [2004] are out of thermodynamic equilibrium in the glass region. At thermodynamic equilibrium, changes in magma temperature result in a change in both the fraction and composition of the residual liquid. Electrical conductivity of rhyolitic glass and melt can be described by a single Arrhenius law [Gaillard, 2004], however, basaltic glass and melt might display different transport properties [Dingwell, 1994]. In particular, electronic conductivity might dominate in the glass region while the liquid is characterized by ionic conduction [Cook and Cooper, 2000; Scarlato et al., 2004; Gaillard, 2004]. 
Table 1. Composition of Starting Materials Normalized to $100 \%{ }^{\mathrm{a}}$

\begin{tabular}{lccccccccc}
\hline & $\mathrm{SiO}_{2}$ & $\mathrm{TiO}_{2}$ & $\mathrm{Al}_{2} \mathrm{O}_{3}$ & $\mathrm{MgO}$ & $\mathrm{FeO}$ & $\mathrm{CaO}$ & $\mathrm{Na}_{2} \mathrm{O}$ & $\mathrm{K}_{2} \mathrm{O}$ & Total \\
\hline $\mathrm{Mer}$ & 54.81 & 0.88 & 19.00 & 3.41 & 7.99 & 9.34 & 3.62 & 1.25 & 99.18 \\
1158 & 59.6 & 1.45 & 14.15 & 4.65 & 6.03 & 7.12 & 4.01 & 2.99 & 98.55 \\
1088 & 65.38 & 1.66 & 14.05 & 2.65 & 4.05 & 4.45 & 4.10 & 3.56 & 98.99 \\
\hline
\end{tabular}

${ }^{a}$ Original EMPA total is given in wt \%.

[8] To increase the current database we measured the electrical behavior of a lava with a basaltic composition during equilibrium crystallization. To attain an ideal control on the crystal content of the samples, we used 1-atm furnace with thermal gradient smaller than $1{ }^{\circ} \mathrm{C}$ in the sample chamber, which avoided disequilibrium or gradients in the crystal content. To discriminate the effect of increasing the crystal fraction from the correlated changes in the liquid composition, we also measured the conductivity of several silicate liquids matching the residual composition of the basaltic system at different temperatures. Our results clearly show that the liquid composition is critical because the effect of the increasing crystal contents on the basalt conductivity is almost compensated by changes in the liquid composition.

\section{Experimental Procedure}

\subsection{Starting Material}

[9] A basaltic pumice of the Merapi volcano was used as a starting material for measuring the conductivity in the crystallizing experiments [Hammer et al., 2000]. This pumice was twice melted, quenched at $1550^{\circ} \mathrm{C}$ and crushed. The chemical composition of the quenched glass is shown in Table 1. The choice of this starting material was motivated by its great kinetics of crystallization, in contrast to the rhyolitic composition used by Gaillard [2004]. In section 3.2 we show that the kinetics of crystallization and the rate of attainment of textural/chemical crystal-liquid equilibrium vary, for this composition, from several seconds to a few hours in the temperature range explored. In addition, above liquidus measurements were conducted on three synthetic silicate liquids matching the composition of the experimental residual liquid of the Merapi basalt at different temperatures. These silicates, obtained by appropriate mixtures of oxides and carbonates, were also melted twice at $1550^{\circ} \mathrm{C}$ and crushed. The composition of these the quenched glasses ranged from andesite to dacite and is also given in Table 1. Cylinders of quenched glass were cored and machined to fit inside the conductivity cell described hereafter. Before each measurement, starting materials were inspected to check for the presence of bubbles. Only bubble-free starting glasses were used.

\subsection{Apparatus and Experimental Conditions}

[10] All measurements were performed in the range of $1000-1350^{\circ} \mathrm{C}$, in a 1 -atm high-temperature furnace equipped with a zircon probe and a gas-mixing device $\left(\mathrm{CO}-\mathrm{CO}_{2}\right)$. All experiments were done at the redox buffer hematite-magnetite (HM), which corresponds to the most oxidizing conditions for terrestrial magmas [Carmichael, 1991]. Such oxidizing conditions were necessary to reduce iron loss from the sample toward the platinum container and electrodes (see hereafter). Also, sodium, that is the major electrical charge carrier in melts, strongly volatilized under reducing conditions, but will remain in the melt at the HM buffer. Our scientific aim was to partially crystallize large and homogeneous samples to measure their electrical conductivity. For this purpose, the 1-atm furnace is the best device. The temperature gradient across the sample chamber is virtually negligible and less than $1^{\circ} \mathrm{C}$. Heterogeneities in crystal content due to a thermal gradient are therefore excluded under these thermal conditions. The second advantage of 1-atm systems is the large volume allowing several simultaneous experiments to be run, which is of critical interest as detailed hereafter.

\subsection{Analyses}

[11] A JEOL electron microprobe was used to characterize the sample before and after experiments. All analyses were conducted at $15 \mathrm{keV}, 6 \mathrm{nA}, 10 \mathrm{~s}$ on peaks and $5 \mathrm{~s}$ on the background. Glasses were analyzed with a defocused beam; a focused beam was used to analyze crystals. Backscatter images were collected to evaluate the textures and crystal contents of run products. However, crystal fractions were quantified by mass balance calculations.

\subsection{Strategy and Electrical Measurements}

[12] All crystallization experiments were run with several samples at a given temperature. The sample whose electrical conductivity was measured in a special cell (Figure 1), whereas in parallel, a set of three samples attached with the loop technique were also run and sequentially quenched at

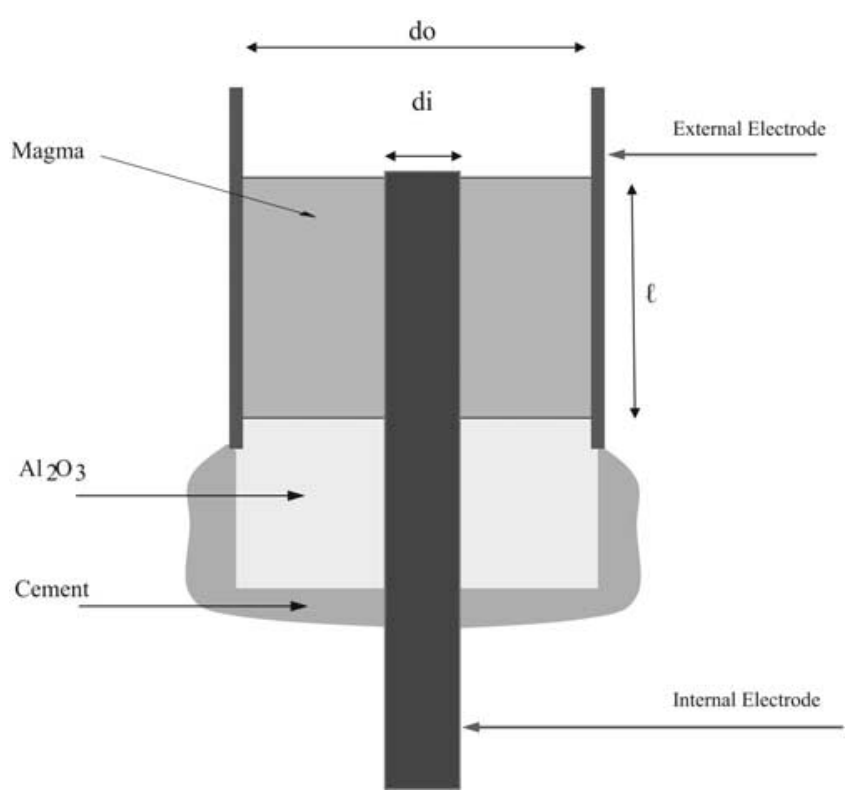

Figure 1. Sketch of the assembly used to perform hightemperature measurements of electrical conductivity in the course of magma crystallization. The radial conductivity cell is composed of an $\mathrm{Al}_{2} \mathrm{O}_{3}$ base on top of which a glass cylinder is placed. The cell geometry is given by the geometry of the initial glass cylinder (do, di, and 1 are explained in text, see equation (2)). This conductivity cell is permanently exposed at temperature. The crystal fraction and phase compositions as a function of temperature are determined from the drop-quenched samples disposed in parallel in the furnace using the classical Pt-wire loop technique. 


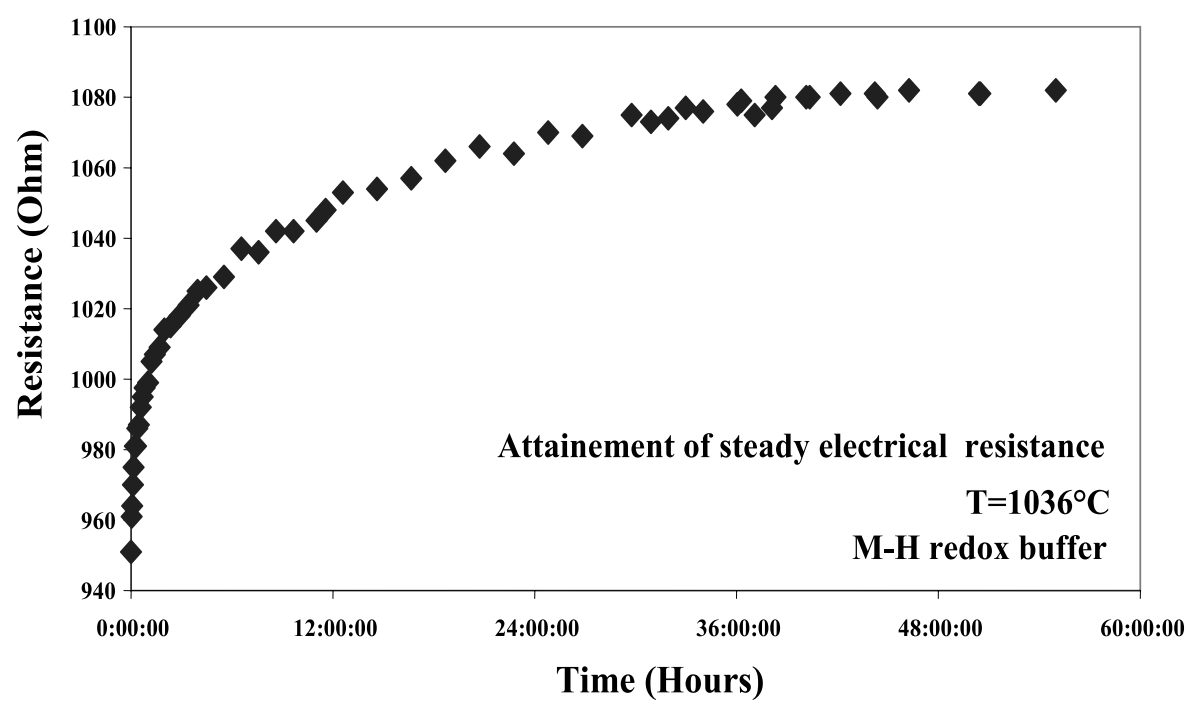

Figure 2. Equilibration rate of the Merapi sample in response to a change in temperature from 1064 to $1041^{\circ} \mathrm{C}$. The resistance increased sharply immediately after the change in temperature and evolved more slowly after a few hours. This conductivity change was followed by a steady regime that is interpreted as crystallization and growth of a new reequilibrated crystal-liquid assembly at $1041^{\circ} \mathrm{C}$. The error bar on each measurement is smaller than the size of the data point.

different temperatures. These quenched samples were examined by electron microprobe analysis for the composition of glass and crystals. The critical advantage of this strategy is that the samples used for measuring conductivity and the ones used for textural and chemical characterization experienced exactly the same $\mathrm{T}-\mathrm{fO}_{2}$-time path. We are therefore fairly confident in the conductivity-crystal contenttemperature relationships that we thus obtained and show in this paper.

[13] A SOLARTRON impedance analyzer was used to measure the electrical impedance of the samples [Gaillard, 2004]. Impedance spectra were collected in the frequency range $10^{6}$ to $0.1 \mathrm{~Hz}$. The procedure of fitting of the impedance arc due to the sample response and the arc caused at sample-electrode interface were similar to the one described by Gaillard [2004]. A radial geometry similar to Gaillard [2004] was used (Figure 1). The upper part of the assembly was open to the atmosphere of the furnace and the lower part was closed by an $\mathrm{Al}_{2} \mathrm{O}_{3}$ plug, in contrast to Gaillard [2004], who used a $\mathrm{SiO}_{2}$ plug. This choice was imposed by the intense reaction observed during preliminary experiments between $\mathrm{SiO}_{2}$ and the basaltic melt at temperature. In contrast, the $\mathrm{Al}_{2} \mathrm{O}_{3}$ plug showed negligible chemical interaction with the melt. After 10 days at temperature, a thin layer $(1 \mu \mathrm{m})$ of $\mathrm{Mg}-\mathrm{Al}-\mathrm{Fe}-\mathrm{O}$ spinel grew at the $\mathrm{Al}_{2} \mathrm{O}_{3}$-melt interface. This layer behaved as a sort of barrier limiting the extent of chemical exchanges between the melt and the $\mathrm{Al}_{2} \mathrm{O}_{3}$ plug. All analyses revealed that melt composition and both crystal composition and fraction near or far from the $\mathrm{Al}_{2} \mathrm{O}_{3}$-sample interface are similar within the uncertainty of the measurements. It should be specified that experiments were conducted at temperature as high as $1350^{\circ} \mathrm{C}$, which underlines the quasi-inert and therefore extremely reliable nature of the assembly we used.

[14] In reality, measurements were done first above the liquidus temperature, which was determined at $1200 \pm 10^{\circ} \mathrm{C}$ by optical inspection of samples rapidly quenched from high-temperature treatment with a step of $10^{\circ} \mathrm{C}$. In the range $1400-1220^{\circ} \mathrm{C}$ and with steps of $20^{\circ} \mathrm{C}$, the electrical conductivity of the basaltic melt was measured. Then, crystallization measurements were conducted in the following manner. From liquidus temperature, the system was cooled down to $25^{\circ} \mathrm{C}$. The associated conductivity changes were measured until a steady value of conductivity was attained (Figure 2). This steady value was interpreted as evidence for crystal-liquid equilibration. Once equilibrium was achieved, a looped sample was drop quenched and used to characterize the crystal content and composition of phases of the basaltic sample at this temperature. Then, another step in temperature decrease was conducted, following the same procedure and each of these steps were performed until $80 \%$ of crystallization was achieved.

[15] The time of equilibration was highly variable depending on temperature. At near-liquidus conditions, equilibrium was almost instantaneously attained because the time required to record an impedance spectra $(1 \mathrm{~min})$ was apparently enough to equilibrate the sample. Around $1100^{\circ} \mathrm{C}$, the required time was several minutes and at temperatures between 1100 and $1030^{\circ} \mathrm{C}$, the duration to reach equilibration was several hours (Figure 2). Below $1030^{\circ} \mathrm{C}$, the time required to equilibrate the sample was considered infinite because even after 10 days at this temperature small but continuous changes were observed without obvious changes in the crystal content $(\sim 80 \%)$. These kinetics changes were obviously related to decreases in temperature, which limit the diffusion rates of elements in the melt. The changes in the residual melt compositions (basalt to rhyodacite) due to partial crystallization were probably responsible for the sluggish crystallization rates at $1000^{\circ} \mathrm{C}$. The residual liquid undergoing enrichment in $\mathrm{SiO}_{2}$ upon crystallization becomes more polymerized and therefore much less reactive [Dingwell, 1994]. For that 
reason, experiments were conducted to temperature down to $1018^{\circ} \mathrm{C}$

\subsection{Calculation and Precision on Electrical Conductivity}

[16] Electrical conductivity was calculated from the measured resistance of the sample and the geometry of the electrical cell according to [Macdonald, 1987; Gaillard, 2004]

$$
\sigma=[\mathrm{R}]^{-1}\left[2 \Pi 1\left(\ln \left(\mathrm{d}_{\mathrm{o}} / \mathrm{d}_{\mathrm{i}}\right)\right)^{-1}\right]^{-1}
$$

The precision on the conductivity is therefore controlled by both resistance measurements $(\mathrm{R})$ and cell geometry $\{1$, the length and $d_{o}$ and $d_{i}$ being the outer and inner diameter of the sample, see Figure 1\}. Uncertainty in resistance was estimated from repeated measurements at a given $\mathrm{T}$. These measurements varied within $1-2 \%$ for a set of 10 measures. In addition, temperature cycles were performed, which consisted in coming back to a reference $\mathrm{T}\left(1250^{\circ} \mathrm{C}\right)$ after a cycle of measurements at lower temperature. The measured resistance at $1250^{\circ} \mathrm{C}$ after variable thermal history of the sample did not vary more than $1-2 \%$. Therefore we recognize the uncertainty in $\mathrm{R}$ to be $2 \%$.

[17] The cell geometry was initially controlled by the size of the glass cylinder $(8 \mathrm{~mm}$ outer diameter, $1 \mathrm{~mm}$ inner diameter). The geometry was checked after the experiments to check for possible changes. Probably due to the large wall thickness of the Pt container, no change in cell diameter was observed. In contrast, because of the wetting properties between $\mathrm{Pt}$ and the basaltic melt, a perfect cylindrical shape was never achievable at the top of the cell. A systematic convex shape at the gas-melt-Pt interface was observed. To reduce this effect of wetting between sample and container for calculations of cell geometry, a large diameter and length for the glass cylinder were used. This reduces changes in sample geometry to within less than $\sim 4 \%$. In all, we considered the uncertainty in conductivity to be less than $5 \%$.

\section{Results}

\subsection{Crystallization and Phase Relationships}

[18] The proportions and compositions of each phase obtained at different temperature are shown on Table 2. Crystals were homogeneously distributed in the sample (Figure 3). No preferential nucleation on the sample rim (interface with the electrode) was detected. Plagioclase appeared as a liquidus phase at $1190^{\circ} \mathrm{C}$. Iron-titanium oxides appeared at $\sim 1160^{\circ} \mathrm{C}$ and clinopyroxene is the last to crystallize phases reaching saturation at $\sim 1120^{\circ} \mathrm{C}$. Over the entire course of crystallization, plagioclase is the dominant mineral and its proportion reached $\sim 60 \mathrm{wt} \%$ at $1016^{\circ} \mathrm{C}$. Clinopyroxenes formed the second most abundant crystal phases. Fe-Ti oxides remained at proportion less than 5 wt \%. In response to partial crystallization, the residual liquid underwent major changes in composition. The most spectacular changes occurred for silica, iron and potassium, with $\mathrm{SiO}_{2}$ increasing from 54 wt $\%$ at the liquidus to 70 wt $\%$ at $1018^{\circ} \mathrm{C}, \mathrm{FeO}$ decreasing from $\sim 10$ to $3 \mathrm{wt} \%$ and $\mathrm{K}_{2} \mathrm{O}$ rising from 2 to $5 \mathrm{wt} \%$ under the same
Table 2. Nature, Proportion, and Composition of the Experimental Phases Obtained at Different Temperatures for the Merapi Sample $^{\mathrm{a}}$

\begin{tabular}{|c|c|c|c|c|c|c|c|c|c|}
\hline & $\begin{array}{c}\text { Phase } \\
\text { Proportion }\end{array}$ & $\mathrm{SiO}_{2}$ & $\mathrm{TiO}_{2}$ & $\mathrm{Al}_{2} \mathrm{O}_{3}$ & $\mathrm{MgO}$ & $\mathrm{FeO}$ & $\mathrm{CaO}$ & $\mathrm{Na}_{2} \mathrm{O}$ & $\mathrm{K}_{2} \mathrm{O}$ \\
\hline \multicolumn{10}{|c|}{$1182^{\circ} \mathrm{C}$} \\
\hline Liquid & 78.00 & 55.16 & 1.02 & 16.34 & 4.24 & 9.70 & 7.76 & 3.63 & 2.14 \\
\hline Plagioclase & 22.00 & 49.57 & 0.00 & 29.89 & 0.10 & 2.02 & 15.17 & 3.03 & 0.20 \\
\hline \multicolumn{10}{|c|}{$1158^{\circ} \mathrm{C}$} \\
\hline Liquid & 60.2 & 57.01 & 1.14 & 14.97 & 4.18 & 8.78 & 6.81 & 3.58 & 2.52 \\
\hline Plagioclase & 37.4 & 52.52 & 0.00 & 27.84 & 0.20 & 2.50 & 12.65 & 3.38 & 0.41 \\
\hline Oxide & 2.3 & 0.40 & 1.34 & 6.00 & 9.00 & 75.50 & 0.10 & 0.00 & 0.00 \\
\hline \multicolumn{10}{|c|}{$1134^{\circ} \mathrm{C}$} \\
\hline Liquic & 55.8 & 58.10 & 1.53 & 13.88 & 5.36 & 8.16 & 7.76 & 3.42 & 2.45 \\
\hline Plagic & 41.6 & 53.20 & 0.00 & 26.60 & 0.20 & 2.97 & 12.63 & 3.99 & 0.41 \\
\hline Oxide & 2.6 & 0.40 & 1.34 & 6.00 & 9.00 & 75.50 & 0.10 & 0.00 & 0.00 \\
\hline \multicolumn{10}{|c|}{$1111^{\circ} \mathrm{C}$} \\
\hline Liqui & 45.6 & 62.40 & 1.46 & 14.04 & 3.33 & 5.93 & 6.14 & 3.85 & 2.86 \\
\hline Plagi & 44.00 & 52.23 & 0.00 & 27.14 & 0.20 & 3.48 & 12.80 & 3.74 & 0.41 \\
\hline Pyroxene & 6.3 & 48.35 & 1.34 & 4.84 & 15.43 & 8.23 & 21.30 & 0.51 & 0.00 \\
\hline Oxide & 4.1 & 0.40 & 2.00 & 5.00 & 10.00 & 75.50 & 0.10 & 0.00 & 0.00 \\
\hline \multicolumn{10}{|c|}{$1088^{\circ} \mathrm{C}$} \\
\hline Liquid & 42.4 & 65.73 & 1.46 & 14.56 & 2.29 & 4.16 & 4.16 & 4.00 & 3.64 \\
\hline Plag & & 50.18 & 0.00 & 29.29 & 0.15 & 3.28 & 13.72 & 8 & 0.10 \\
\hline Pyrox & 11.4 & 49.35 & 1.40 & 4.67 & 17.21 & 7.98 & 18.87 & 0.52 & 0.00 \\
\hline Oxide & 4.8 & 0.40 & 2.00 & 5.00 & 10.00 & 75.50 & 0.10 & 0.00 & 0.00 \\
\hline \multicolumn{10}{|c|}{$1064^{\circ} \mathrm{C}$} \\
\hline Liqui & 33.60 & 67.90 & 1.50 & 14.10 & 1.88 & 3.60 & 3.40 & 3.77 & 4.20 \\
\hline Plagi & 48.4 & 52.05 & 0.00 & 27.45 & 0.20 & 3.15 & 13.12 & 4.07 & 0.35 \\
\hline Pyroxene & 12.70 & 49.09 & 1.42 & 4.59 & 17.23 & 8.10 & 18.29 & 0.44 & 0.00 \\
\hline Oxide & 5.30 & 0.40 & 4.30 & 4.20 & 7.60 & 75.78 & 0.10 & 0.00 & 0.00 \\
\hline \multicolumn{10}{|c|}{$1041^{\circ} \mathrm{C}$} \\
\hline Liquid & 27.2 & 69.29 & 1.55 & 13.44 & 1.55 & 3.36 & 2.79 & 3.46 & 4.55 \\
\hline Plag & & 53.19 & 0.00 & 26.44 & 0.20 & 3.01 & 12.04 & 4.62 & 0.50 \\
\hline Pyro & 13.2 & 49.04 & 1.42 & 4.55 & 17.29 & 9.10 & 18.20 & 0.40 & 0.00 \\
\hline Oxide & 5.2 & 0.40 & 4.50 & 4.20 & 7.60 & 75.70 & 0.10 & 0.00 & 0.00 \\
\hline \multicolumn{10}{|c|}{$1018^{\circ} \mathrm{C}$} \\
\hline Liq & 22. & 70.55 & 1.59 & 13.02 & 1.51 & 3.10 & 2.41 & 3.44 & 4.82 \\
\hline & 57. & 54.09 & 0.00 & 25.77 & 0.27 & 2.79 & 12.21 & 4.68 & 0.75 \\
\hline Pyroxene & 15.00 & 49.94 & 1.55 & 4.44 & 17.25 & 9.22 & 17.69 & 0.38 & 0.00 \\
\hline Oxide & 5.10 & 0.34 & 4.70 & 3.90 & 6.10 & 75.20 & 0.15 & 0.00 & 0.00 \\
\hline
\end{tabular}

conditions. Important for the following parts is to notice that the sodium content remained almost constant in the liquid along the entire crystallization path $\left(\mathrm{Na}_{2} \mathrm{O}\right.$ varied between 3.3 and $4 \mathrm{wt} \%$ ) because plagioclase, the dominant crystallizing phase, contained almost the same $\mathrm{Na}$ content as the residual liquid.

\subsection{Electrical Conductivity}

[19] Results of electrical conductivity measurements on the Merapi basalt during crystallization are shown in Figure 3. Open symbols show the measurements performed above the liquidus; half open symbols refer to partially crystallized samples. As a sample started to crystallize at $\mathrm{T}<$ $1200^{\circ} \mathrm{C}$, its electrical conductivity negatively deviated from extrapolation toward low temperature of the Arrhenius law fitted for the above liquidus region. The magnitude of the deviation from the Arrhenius law is, however, not monotonic and for the lowest temperature $\left(1100-1018^{\circ} \mathrm{C}\right)$, corresponding to the liquid fraction of $\sim 35-20 \mathrm{wt} \%$, the 


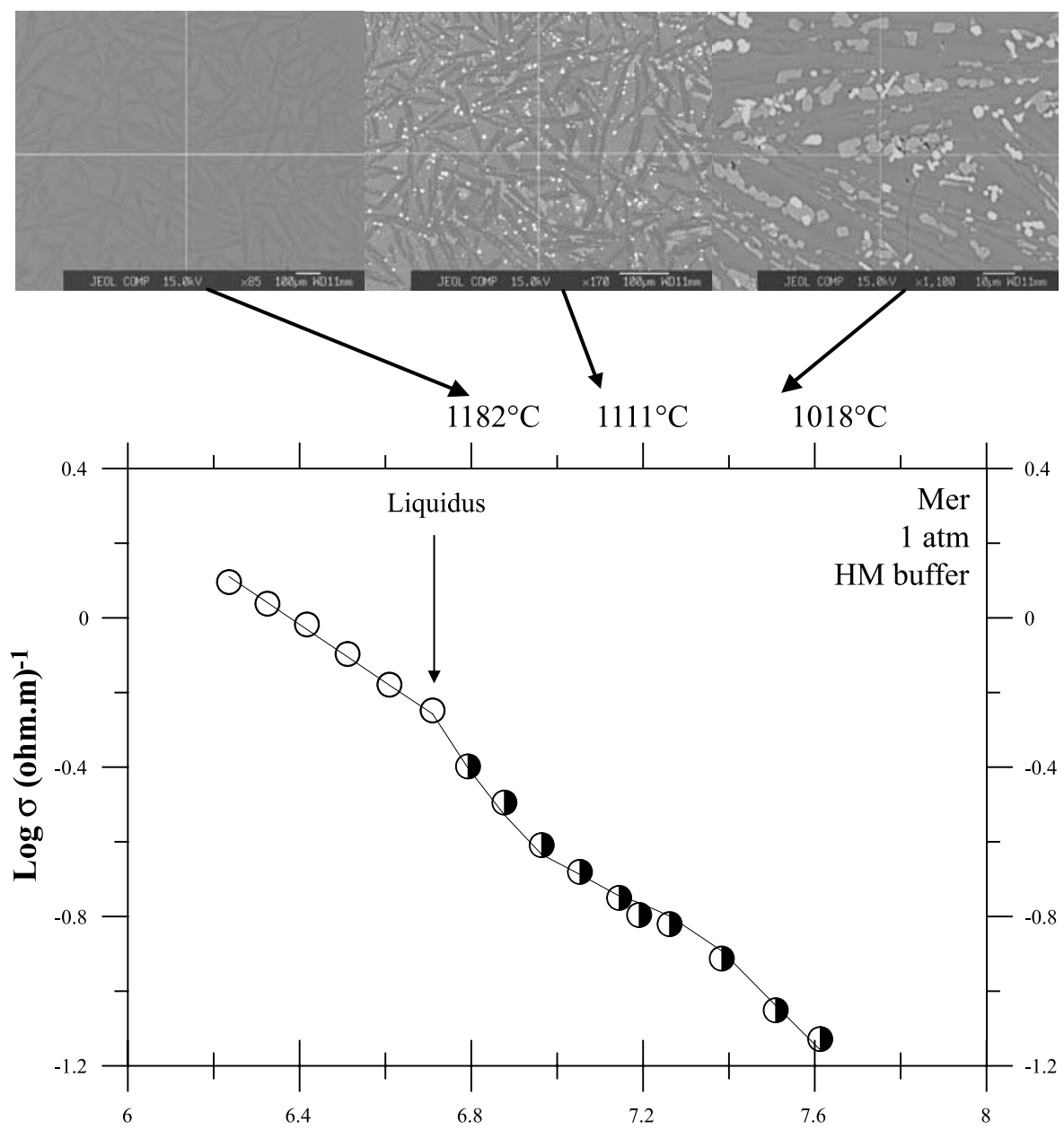

$10,000 / \mathrm{T}^{\circ} \mathrm{K}$

Figure 3. (bottom) Electrical conductivity measurements versus temperature for the Merapi sample during partial crystallization. (top) SEM images of the amount of crystals at different temperatures. Open symbols represent above-liquidus measurements and half solid circles correspond to samples that underwent partial crystallization. The line passing through the data is the fit discussed in the section 5.1, which corresponds to the combination of equations (4), (5) and (6). The error bar on each measurement is about half of the size of the point.

conductivity of the crystallizing sample became closer to the extrapolation of this Arrhenius law.

[20] The electrical behavior of the liquids investigated is shown in Figure 4. The three compositions, labeled Mer1158-1088, obey to an Arrhenius law in the temperature range of the experiments. The conductivity of the more evolved liquid $1088\left(\mathrm{SiO}_{2} \sim 65 \mathrm{wt} \%\right)$ is higher than the Merapi basalt $\left(\mathrm{SiO}_{2} \sim 54 \mathrm{wt} \%\right)$ by one log unit at $1000^{\circ} \mathrm{C}$ (extrapolation). These data indicate that the electrical conductivity of residual melt strongly increases as the magma crystallizes. The Arrhenius law fitted to the three sets of data revealed that the activation energies are 110,82 , and $71 \mathrm{KJ}$ for sample Mer-1158-1088, respectively.

\section{Interpretation}

\subsection{Adjustment of the Modified Archie's Law}

[21] Figure 4 clearly shows some major changes in the electrical conductivity of the residual liquid as crystalliza- tion proceeds. These changes in electrical behavior in fact reflect modifications in the chemical composition of the liquid that affect the mechanisms of conduction. In Figure $5 \mathrm{a}$, the changes in the residual liquid composition are shown as a function of the temperature. Surprisingly sodium, which is expected to be the principal charge carrier, does not significantly change in the residual liquid during partial crystallization. The most spectacular changes are observed for $\mathrm{SiO}_{2}$ and $\mathrm{K}_{2} \mathrm{O}$ both increasing from 54 and 1.5 to 70 and $5 \mathrm{wt} \%$, respectively. The changes in electrical properties of the residual liquid at different temperature can be rationalized as an expression of a preexponential term and activation energy extracted from an Arrhenius fit to the data in Figure 4. These Arrhenius parameters describing the electrical behavior of the residual liquid are plotted in Figure $5 \mathrm{~b}$ as a function of temperature. Both preexponential and activation energy terms for the residual liquid decrease drastically as the temperature decreases. It appears therefore that the electrical conductivity of the residual liquid cannot 


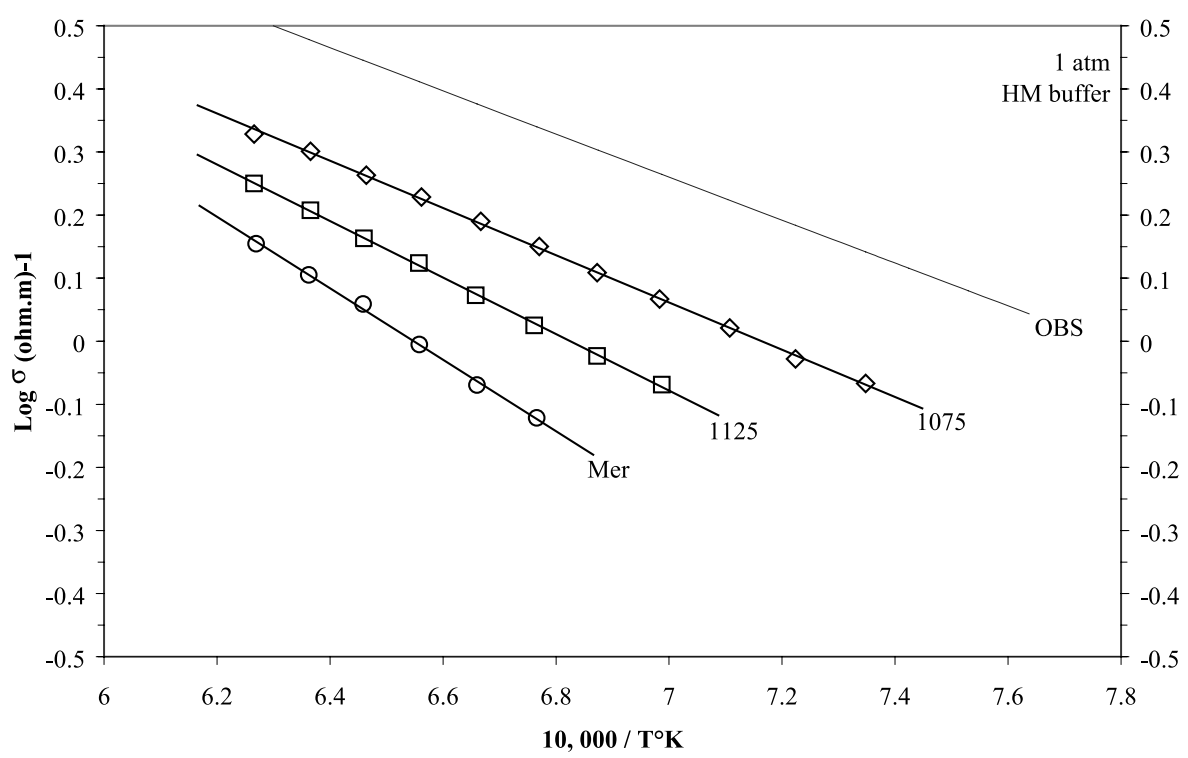

Figure 4. Conductivity measurements performed on the liquid samples (see Table 1). OBS is the electrical conductivity of a rhyolitic liquid calculated at $1 \mathrm{~atm}$ according to Gaillard [2004].

be modeled with a single Arrhenius plot. To model the electrical conductivity of our magma in the course of crystallization, we need to take into account these changes in the Arrhenius parameters resulting from changes in residual liquid composition. We defined the conductivity of silicate liquids as a linear function of reciprocal temperature:

$$
\log \sigma=\mathrm{a}+\mathrm{bT}^{-1}
$$

with $\mathrm{a}$ and $\mathrm{b}$ being two constants, defined by the $\mathrm{K}_{2} \mathrm{O}$ content of the liquid:

$$
\begin{array}{lll}
\mathrm{a}=\mathrm{a}_{1}+\mathrm{a}_{2}\left(\mathrm{~K}_{2} \mathrm{O} \text { wt } \%,\right) & \mathrm{a}_{1}=0.742 ; & \mathrm{a}_{2}=-0.105 \\
\mathrm{~b}=\mathrm{b}_{1}+\mathrm{b}_{2}\left(\mathrm{~K}_{2} \mathrm{O} \text { wt } \%,\right) & \mathrm{b}_{1}=4.742 ; & \mathrm{b}_{2}=-0.60
\end{array}
$$

The parameters $a$ and $b$ were expressed as a function of potassium content in the melt because variations in the $\mathrm{K}_{2} \mathrm{O}$ content of the residual liquid during fractionation were the most spectacular. Furthermore, in the literature of material sciences, a mixed-alkalis effect (effect of $\mathrm{K} / \mathrm{Na}$ ratio on electrical conductivity) was well documented emphasized and shown to be a major parameter controlling the conductivity of chemically simple silicate melts [Greaves and Ngai, 1995]. We expressed the changes in electrical properties of the liquid as a linear function of potassium content, adopting the simplest mathematical function that describes the conductivity of the liquids shown in Figure 4 with the best accuracy.

[22] Combination of equations (3), (4), and (5) allows the changes in electrical conductivity of the residual liquid to be calculated in the investigated temperature range of partial crystallization $\left(1200-1018^{\circ} \mathrm{C}\right)$. The electrical conductivity of the solid crystals was not measured in our study. We adopted the Arrhenius law given by Partzsch et al. [2000] that was extracted from measurements on a Gabro-Norite crystalline rock in the temperature range of $850-1030^{\circ} \mathrm{C}$.
This rock was described as being composed dominantly of plagioclase and pyroxene (60 and $34 \mathrm{vol} \%$, respectively) and is therefore extremely similar to our crystals assemblage. The modified Archie's law [Glover et al., 2000a] was used to model the electrical conductivity of our crystal + liquid system at different temperatures. It has the following form:

$$
\left.\sigma_{\text {magma }}=\sigma_{c r} \%_{c r}^{\left(\frac{\log (1-\% m}{\log (1-\% \text { liq }}\right)}\right)+\sigma_{\text {liq }} \%_{\text {liq }}^{m}
$$

The exponent term " $m$ " represents the connectivity of the liquid phase according to Glover et al. [2000a]. The parameter $\sigma$ refers to the electrical conductivity and percent to the volume fraction of the corresponding subscript. The proportions given in Table 2 expressed as wt \%, were calculated as equivalent volume percent. The density of silicate liquids at $\mathrm{T}$ was calculated after Lange and Carmichael [1990], and the crystals density at $\mathrm{T}$ was calculated using the supplemental calculator of the MELTS package [Ghiorso and Sack, 1995]. At $1<\mathrm{m}<1.2$, the modified Archie's law is very similar to other models such as the modified "bricklayer" model or the Hashin-Strikman upper bound or the Waff model [Waff, 1974; see Glover et al., 2000a, and reference therein].

[23] The data shown in Figures 3 and 4 were fitted using equations (6) with the conductivity of the residual liquid being defined by equations (3), (4), and (5). The results of the fit are shown in Figures 3 and 4. The exponent $\mathrm{m}=1.05$ yielded the best fit to the data. According to Glover et al. [2000a], the $\mathrm{m}$ value reflects the connectivity of the liquid phase. For $\mathrm{m}<2$ the connectivity is considered high; for $\mathrm{m}$ $>2$, it is low. The values we obtained with our fit, 1.05, are consistent with what would be expected from other theoretical models considering a fully interconnected silicate 

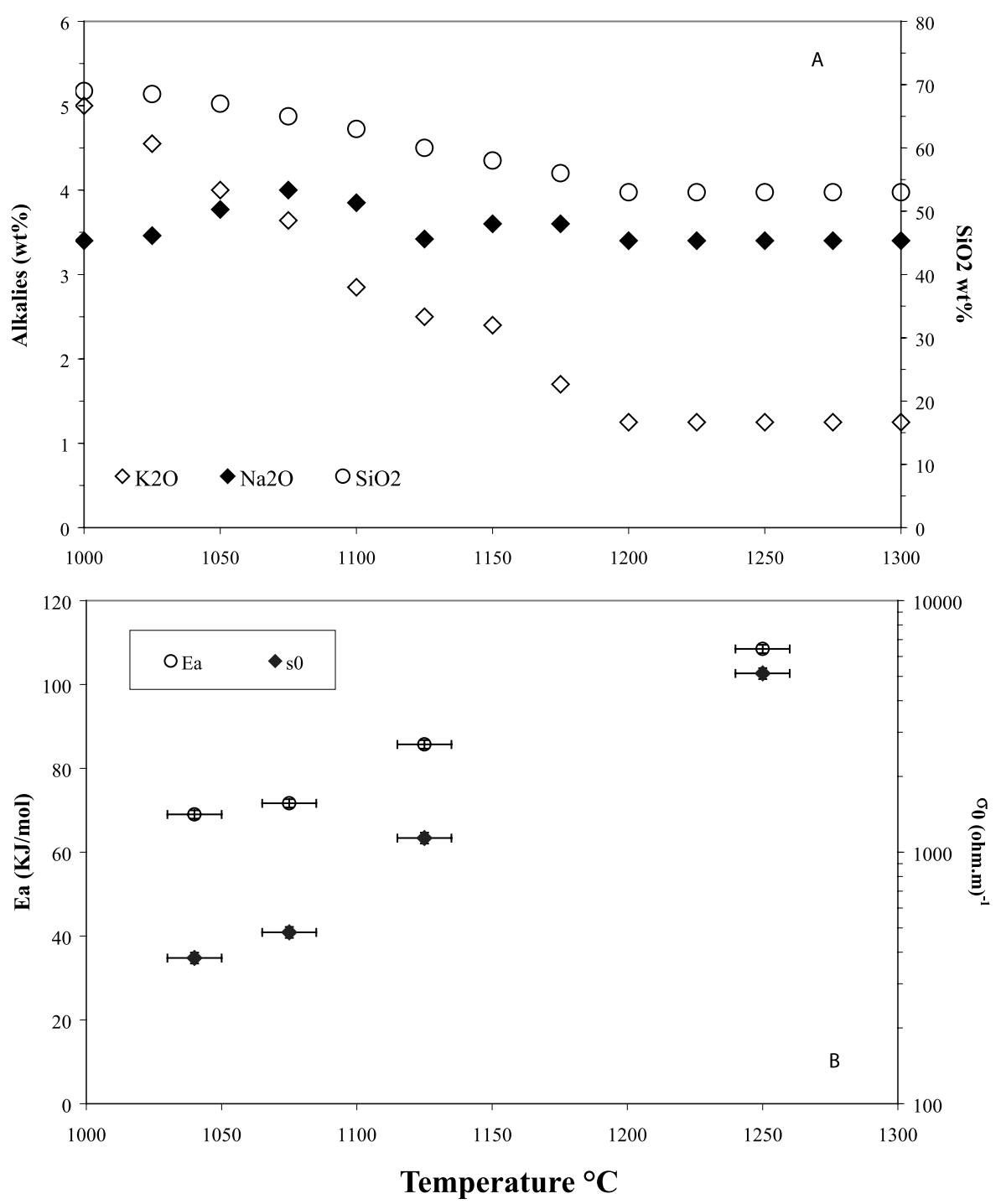

Figure 5. (a) Changes in the chemical composition of the residual liquid upon crystallization ( $\mathrm{Na}, \mathrm{K}, \mathrm{Si})$ as a function of temperature. (b) Preexponential terms and the activation energy for electrical conductivity of residual silicate melt versus temperature indicate that the residual liquid cannot be reproduced using a single Arrhenius equation. The data are extracted from fit on Figure 4 plus Gaillard [2004] for the lowest temperature.

melt network [Hashin and Shtrikman, 1962; Waff, 1974; Glover et al., 2000a; Parztsch et al., 2000]. This conclusion is entirely consistent with the findings of Presnall et al. [1972], Roberts and Tyburczy [1999], and Partzsch et al. [2000].

[24] As described in section 4.1, in response to the imposed oxidizing conditions, a significant proportion of Fe-Ti magnetite, up to $5 \mathrm{wt} \%$, precipitated from the melt. According to the work of Nell et al. [1989], such crystals should be a much better conductor than the average of the crystals and probably more conductive than the melt. Subsequently, these conductive crystals were subtracted from the vol \% of insulating crystal considered in equation (6).

\subsection{Petrological Controls on Geophysics}

[25] The sigmoid shape drawn through by the data points in Figures 4 and 5 is well reproduced using equation (6) and is in fact due to the adjustment in the liquid composition as the magma crystallizes, which affects the liquid conductivity. Calculations revealed that the change in residual liquid conductivity is compensated by the temperature effects on silicate-melt conductivity. Clearly, the conductivity of the residual liquid is almost constant during magma crystallization and it does not follow an Arrhenius law. This might explain many of the difficulties to model experimental data on partial melting or partial crystallization and this petrological control must absolutely be taken into account for modeling geophysical data relevant to magmatic regions [Glover et al., 2000b; Park and Ducea, 2003]. At this point, we should admit that the intuitive assumption of Roberts and Tyburczy [1999], who considered a fixed value for the conductivity of the liquid during partial melting, is here demonstrated. However, we interpret this constant conductivity versus temperature as being specific for the course of 
crystallization controlled by the phase equilibria of our system. The chemical changes in the residual liquid are essentially controlled by the crystals assemblages growing from the melt, which is, in turn, controlled by the bulk composition of the magma and thermodynamic parameters such as $\mathrm{P}, \mathrm{fO}_{2}, \mathrm{fH}_{2} \mathrm{O}$ [Osborn, 1959; Hamilton et al., 1964; Sisson and Grove, 1993; Toplis and Carroll, 1995; Scaillet et al., 1995; Pichavant et al., 2002]. The high $\mathrm{fO}_{2}$ of our experiments, which are, for example, encountered in arc magmas, facilitated Fe-Ti oxides crystallization leading to strong enrichments in $\mathrm{K}_{2} \mathrm{O}$ and $\mathrm{SiO}_{2}$ of the residual liquid [Hamilton et al., 1964]. Under more reduced conditions typical of MORB, [Carmichael, 1991; Toplis and Carroll, 1995], such silica enrichments would not be expected. Therefore the conductivity changes we observed in our experiments remain true as a general tendency but it will not systematically happen in nature following the same equations (4), (5), and (6). Our experiments reveal that the nature of the residual molten silicate is critical in modeling the electrical properties of a partially molten or a partially crystallized system. We consequently consider that modeling of magnetotelluric data in magmatic regions must be performed by thorough combinations of petrological and laboratory constraints. Gaillard et al. [2004] and Park and Ducea [2003] are probably the only studies that made this effort of bridging petrological and geophysical constraints for a specific geological site. However, Park and Ducea [2003] modeled the electrical behavior of the mantle during partial melting with less than $2 \%$ basaltic liquid undergoing no significant changes in composition. Similarly, Gaillard et al. [2004] calculated the changes in conductivity of leucogranites in the course of crystallization, which as a result of their quasi-eutectic composition, do not undergo significant changes in the residual liquid compositions. Our study shows that in the case of major changes in residual liquid composition, the associated changes in electrical conductivity of the liquid are critical. We therefore need some additional laboratory constraints on the relationships between electrical conductivity and chemical composition of silicate liquids.

\subsection{Charge Carriers in the Liquid From Basalt to Rhyolite}

[26] Figure 4 shows the change in the electrical properties of liquids ranging from basalt to dacite-rhyolite. Clearly, the conductivity increases as the liquid becomes more differentiated. Changes in the activation energy from 110 to $70 \mathrm{KJ} / \mathrm{mol}$ from $\mathrm{SiO}_{2}$ ranging from 53 to $70 \mathrm{wt} \%$. In Figure 5, one can appreciate the decrease in both the preexponential term and activation energy as the liquid becomes more evolved. Following the hypotheses of previous workers [see Tyburczy and Waff, 1985, and reference therein], Gaillard [2004] demonstrated his conductivity data to be exclusively controlled by sodium content and mobility in the melt. To achieve this point, he showed that the Nernst-Einstein equation could be successfully applied to his data. This equation was applied as

$$
\sigma_{\text {melt }}=\mathrm{D}_{\mathrm{Na}} \mathrm{q}_{\mathrm{Na}}^{2} \mathrm{~N}_{\mathrm{Na}}[\mathrm{kT}]^{-1}\left[\mathrm{H}_{\mathrm{r}}\right]^{-1}
$$

$\mathrm{D}, \mathrm{q}$, and $\mathrm{N}$ refer to the mobility, charge and concentration of sodium ions, respectively, $\mathrm{k}$ is Boltzmann constant, $\mathrm{T}$ is the temperature, and $\mathrm{H}_{\mathrm{r}}$ is the Haven ratio, revealing the mechanisms of $\mathrm{Na}$ migration in the melt. Given that the $\mathrm{Na}$ concentration of our liquid sample is almost the same (Figure 5), the changes in conductivity we observed cannot be attributed to change in the $\mathrm{N}_{\mathrm{Na}}$ term. Literature data on $\mathrm{D}_{\mathrm{Na}}$ in molten silicate revealed a strong control by liquid composition [Jambon, 1982; Henderson et al., 1985; Watson, 1994]. In common with all alkali cations, sodium mobility is greater in silica-rich polymerized liquid than in a silica-poor depolymerized liquid. At this point, one should notice that this alkali behavior is the opposite of other components of a silicate melt, whose mobility generally increases as $\mathrm{SiO}_{2}$ decreases [Mungall, 2002; Reid et al., 2003]. Such a compositional dependency of $D_{\mathrm{Na}}$ perfectly agrees with the composition dependence of electrical conductivity we identified, e.g., $\sigma$ increasing as $\mathrm{SiO}_{2}$ content increases. Following the approach of Gaillard [2004], we calculated using equation (7) the electrical conductivity from available diffusion data on $\mathrm{Na}$ in molten basalt, andesite, and rhyolite [Henderson et al., 1985; Jambon, 1982] (see Figure 6a caption). These calculated values are shown in Figure $6 a$ together with conductivity obtained through equation (3)-(5). To calculate conductivity from equation (7), we fixed the $\mathrm{Na}_{2} \mathrm{O}$ content to $4 \mathrm{wt} \%$, to be consistent with our database (Tables 1 and 2). The calculated conductivities from $\mathrm{D}_{\mathrm{Na}}$ with a Haven ratio of 1 agree fairly well with the values calculated from the equations (3), (4), and (5) for a rhyolite composition. Both activation energy and preexponential terms are reasonably similar. For andesite and basalt liquid, the conductivity calculated from $\mathrm{Na}$ diffusion requires a Haven ratio equal to 0.6 and 0.4 , respectively, to match the measured conductivities. This indicates that the mechanisms of $\mathrm{Na}$ migration differ between polymerized and depolymerized liquids. This supports strongly the idea that $\mathrm{Na}$ is the dominant charge carrier from basalts to rhyolites and that the conductivity of natural silicate melts can be predicted using the NernstEinstein equation. However, we need to know how $\mathrm{D}_{\mathrm{Na}}$ varies with composition and to interpret such changes in the Haven ratio.

[27] Figure 4 shows the effect of melt composition on electrical conductivity. The increase in conductivity associated with differentiation of the melt is due to the correlated decrease in both preexponential term and activation energy. This is graphically illustrated in Figure 4 by the fact that all data point to a common value at high temperature. This behavior, called compensation effect, has been reported for the diffusion of different elements in multicomponent silicate melts by Henderson et al. [1985, and references therein] and previous workers. Interesting was that alkalis were shown to obey to a compensation law markedly different from other elements indicating a particular migration mechanisms. More recently, $W u$ and Zheng [2003] articulated an elegant model for the compensation effect in minerals corroborated by similar observations in melts. The activation energy and preexponential terms for diffusion in minerals were shown to correlate with ionic porosity (see discussion hereafter). On Figure 6b, preexponential term of the Arrhenius fit of our data (Figure 4) is plotted against the corresponding activation energies. The data of Gaillard [2004] obtained on hydrous rhyolites are also plotted with the fit of Tyburczy and Waff [1985] calibrated 

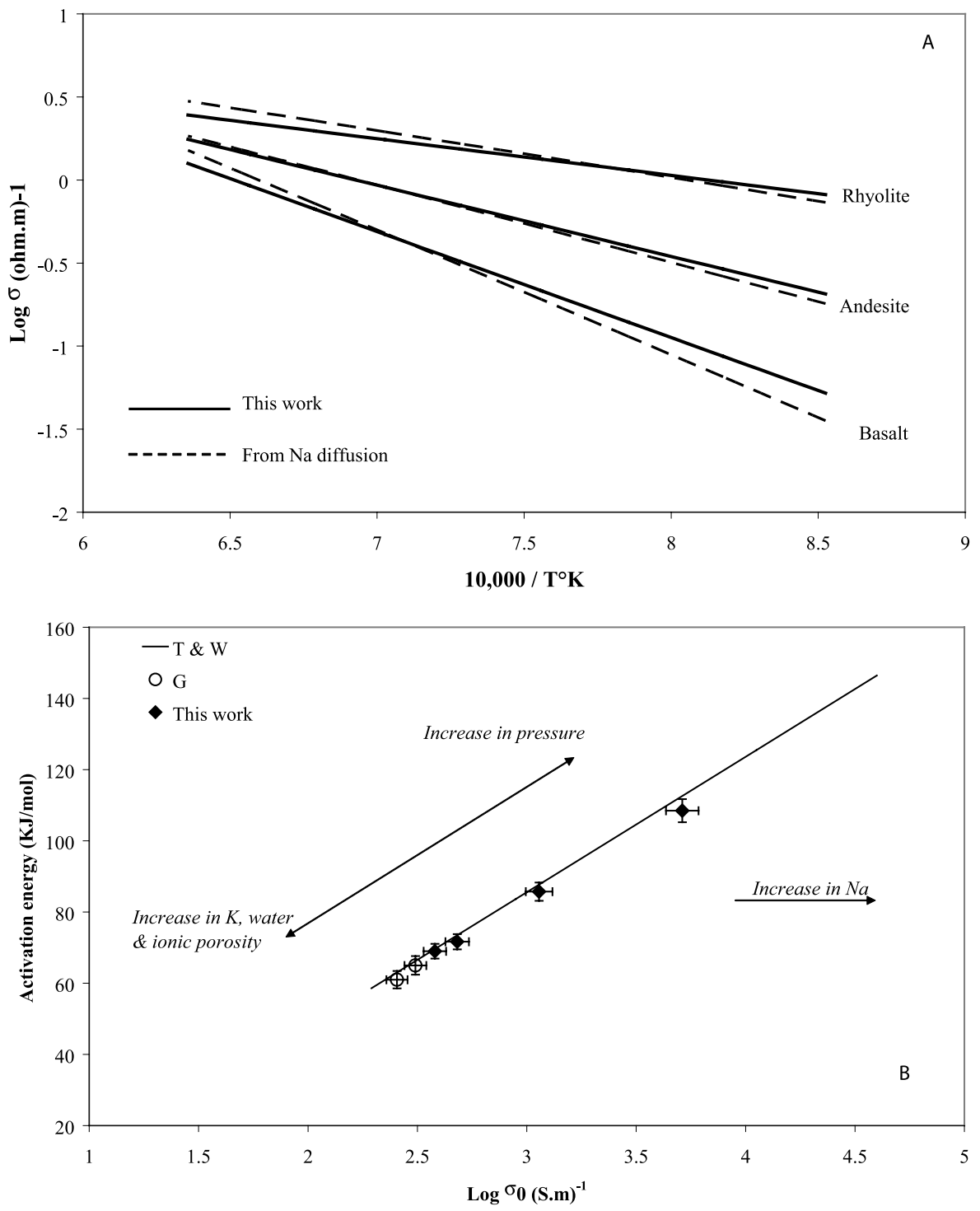

Figure 6. (a) Comparison between electrical conductivity of molten silicate from this study and electrical conductivity calculated from the Nernst-Einstein equation (7) combined with available $\mathrm{Na}$ tracer diffusion (see section 5.3 for details). The solid lines shows measured conductivities, whereas the dashed lines are for Na diffusion data. For andesite and basalt a Haven ratio different from 1 has been used. (b) Compensation plot for the conductivity of multicomponents liquid. Data point from this work, basalt, andesite, dacite and Gaillard [2004], hydrous rhyolites. The line is the fit proposed by Tyburczy and Waff [1985]. Arrows indicate how the Arrhenius parameters would evolve with changes in physicochemical parameters.

on high-pressure experimental data on basalt and andesite liquids. All the data seem to plot on a single trend illustrating the predictive capability of such a compensation law. The arrows qualitatively indicate the evolution of the Arrhenius parameters with physico-chemical changes (see Figure $6 \mathrm{~b}$ caption).

[28] The Haven ratio was demonstrated to be 1 for dry and hydrous silicic compositions by Gaillard [2004]. This implies that $\mathrm{Na}$ ions migrate in such polymerized melt structure via "interstitial" sites [Heinemann and Frischat, 1992]. The term interstitial in a molten silicate is relatively uncertain. This probably refers to the nonoccupied volume in the structure of the melt, at an atomic scale. At this point, we need to introduce the concept of ionic porosity, cited above and developed by Carroll and Stolper [1993]. The value of ionic porosity is established as the ratio of the volume of cations and anions contained in $1 \mathrm{~g}$ of melt over the specific melt volume. It basically defines the melt porosity at an atomic scale. Generally, the more polymerized is the structure of the melt, the more porous will be the melt. Silica rich compositions show large vacant cavities whereas basaltic compositions are extremely compact and show almost no porosity. This reduction in melts porosity, as the $\mathrm{SiO}_{2}$ content of the melt decreases, is consistent with the observation that $\mathrm{Na}$ ions become apparently less mobile in a liquid of basaltic composition in comparison to silica 
richer liquid. A decrease in ionic porosity would mean a decrease in the number or the volume of interstitial sites and therefore a decrease in conductivity. The fact that the Haven ratio is so different between rhyolite and andesite-basalt might indicate that interstitial migration of $\mathrm{Na}$ does not operate in depolymerized liquid because of low ionic porosity. More correlated jumps (a low Haven ratio) during $\mathrm{Na}$ migration in andesite-basalt might operate as proposed by Tyburczy and Waff [1985], which would imply that the mechanisms of Na migration in these melts would be more similar to other cations. This change in mechanisms of $\mathrm{Na}$ migration is consistent with an effect of pressure on electrical conductivity that is very high for a silica-rich and insignificant for a silica-poor composition [Tyburczy and Waff, 1983, 1985; Gaillard, 2004; Scarlato et al., 2004]. In addition, Gaillard [2004] showed that water increases the electrical conductivity of a silicic melt, which is consistent with the findings of Nuccio and Paonita [2000] revealing that incorporation of $\mathrm{H}_{2} \mathrm{O}$ increases the ionic porosity of a silicate melt. Therefore, on the basis of the above statements, we consider the electrical conductivity of a silicate melt to be essentially controlled by the sodium content and ionic porosity of the melt. A quantitative test of this concept is so far premature given the numerous gaps in the experimental database on electrical conductivity of molten silicates. This will be used as a working hypothesis for future experimental work and modeling of electrical properties of natural molten silicate.

\section{Conclusion}

[29] We reported experimental work elucidating the changes in electrical conductivity associated with partial crystallization of a basaltic magma. We identified the conductivity changes as a consequence of both an increase in the crystal fraction and correlated adjustments in the residual liquid composition. The conductivity changes of the residual liquid in response to changes of its chemical composition were separately characterized through additional above liquidus electrical measurements. In all, we formulated an equation allowing the calculation of electrical conductivity of a magma in the course of crystallization. Sodium is identified as the dominant charge carrier from basalt to rhyolite melts and the conductivity changes of the residual liquid are attributed to change in the sodium mobility controlled by the chemical composition of the melt. Basically, a melt becomes more conductive as it is more fractionated, e.g., its $\mathrm{SiO}_{2}$ content increases. Because a liquid having the composition of a dacite at $1000^{\circ} \mathrm{C}$ is more than one $\log$ unit more conductive than a basalt, the chemical controls on electrical conductivity of the residual liquid are shown to be critical. This work underlines the need to integrate the interpretation of the geophysical signature of magmatic region in a relevant petrological framework.

[30] Acknowledgments. Oliver Spieler, who provided the Merapi sample, is warmly thanked. H. Schulze is gratefully acknowledged for his careful technical assistance. Two anonymous reviewers and Doug Schmitt (Associated Editor) provided extremely useful and thorough comments that improve the manuscript. Jeanette Panning, Frans Rietmeijer, and Richard Arculus provided help for the editing of the manuscript. This work was supported by the visitor program of the BGI.

\section{References}

Brasse, H., P. Lezaeta, V. Rath, K. Schwalenberg, W. Soyer, and V. Haak (2002), The Bolivian Altiplano conductivity anomaly, J. Geophys. Res., 107(B5), 2096, doi:10.1029/2001JB000391.

Carmichael, I. S. E. (1991), The redox state states of basic and silicic magmas: A reflection of their source regions, Contrib. Mineral. Petrol., 106, 129-141.

Carroll, M. R., and E. M. Stolper (1993), Noble gas solubilities in silicate melts and glasses: New experimental results for argon and the relationship between solubility and ionic porosity, Geochim. Cosmochim. Acta, 57, 23-24, 5039-5051

Constable, S., T. J. Shankland, and A. Duba (1992), The electrical conductivity of an isotropic mantle, J. Geophys. Res., 97, 3397-3404.

Cook, G. B., and R. F. Cooper (2000), Iron concentration and the physical processes of dynamic oxidation in alkaline earth aluminosilicate glass, Am. Mineral., 85, 397-406.

Dingwell, D. B. (1994), Relaxation theory in silicate melts, in Structure, Dynamics and Properties of Silicate Melts, Rev. Mineral., vol. 32, edited by J. Stebbins, P. F. McMillan, and D. B. Dingwell, pp. 23-48, Mineral. Soc. of Am., Washington, D. C.

Gaillard, F. (2004), Laboratory measurements of electrical conductivity of hydrous and dry silicic melts under pressure, Earth Planet. Sci. Lett., 218, $215-228$.

Gaillard, F., B. Scaillet, and M. Pichavant (2004), Evidence for present-day leucogranite pluton growth in Tibet, Geology, 32, 801-804.

Ghiorso, M. S., and R. O. Sack (1995), Chemical mass transfers in magmatic processes: IV. A revised and internally consistent thermodynamic model for the interpolation and extrapolation of liquid-solid equilibria in magmatic systems at elevated temperatures and pressures, Contrib. Mineral. Petrol., 90, 197-212.

Glover, P. W. J., M. J. Hole, and J. Pous (2000a), A modified Archie's law for two-conducting phases, Earth Planet. Sci. Lett., 180, 369-383.

Glover, P. W. J., J. Pous, P. Queralt, J. A. Munoz, L. Montserrat, and M. J. Hole (2000b), Integrated two-dimensional lithospheric conductivity modeling in the Pyrenees using field-scale and laboratory measurements, Earth Planet. Sci. Lett., 178, 59-72.

Greaves, G. N., and K. L. Ngai (1995), Relating the atomic structure of alumino-silicate glasses to their ionic transport properties, J. Non Crystal. Solids, 192, 405-410.

Hamilton, D. L., C. W. Burnham, and E. F. Osborn (1964), The solubility of water and effects of oxygen fugacity and water content on crystallization in mafic magmas, J. Petrol., 5(1), 21-39.

Hammer, J. E., K. V. Cashman, and B. Voight (2000), Magmatic processes revealed by textural and compositional trends in Merapi dome lavas, J. Volcanol. Geotherm. Res., 100, 165-192.

Hashin, Z., and A. Shtrikman (1962), Variational approach to the theory of effective magnetic permeability of multiphase materials, J. Appl. Phys., 33, 3125-3131.

Heinemann, I., and G. H. Frischat (1992), The sodium transport mechanism in $\mathrm{Na}_{2} \mathrm{O}_{2} \mathrm{SiO}_{2}$ glass determined by the Chemla experiments, Phys. Chem. Glasses, 34, 255-260.

Henderson, P., J. Nolan, G. C. Cunningham, and R. K. Lowry (1985), Structural controls and mechanisms of diffusion in natural silicate melts, Contrib. Mineral. Petrol., 89, 263-272.

Hoffmann-Rothe, A., O. Ritter, and V. Haak (2001), Magnetotelluric and geomagnetic modeling reveals zones of very high electrical conductivity in the upper crust of central Java, Phys. Earth Planet. Inter., 124, 131151 .

Huebner, J. S., and R. G. Dillenburg (1995), Impedance spectra of hot, dry silicate minerals and rocks: Qualitative interpretation of spectra, Am. Mineral., 80, 46-64.

Jambon, A. (1982), Tracer diffusion in granitic melts: Experimental results fro $\mathrm{Na}, \mathrm{K}, \mathrm{Rb}, \mathrm{Cs}, \mathrm{Ca}, \mathrm{Sr}, \mathrm{Ba}, \mathrm{Ce}, \mathrm{Eu}$ to $1300^{\circ} \mathrm{C}$ and a model of calculation, J. Geophys. Res., 87, 797-810.

Lange, R. A., and I. S. E. Carmichael (1990), Thermodynamic properties of silicate liquids with emphasis on density, thermal expansion and compressibility, Modern Methods of Igneous Petrology: Understanding Magmatic Processes, Rev. Mineral., vol. 24, edited by J. Nicholls and J. K. Russell, pp. 25-64, Am. Mineral. Soc., Washington, D. C.

Macdonald, J. R. (1987), Impedance Spectroscopy, Emphasizing Solid Materials and Systems, 346 pp., John Wiley, Hoboken, N. J.

Mungall, J. E. (2002), Empirical models relating viscosity and tracer diffusion in magmatic silicate melts, Geochim. Cosmochim. Acta, 66, 125143.

Nell, J., B. J. Wood, and T. O. Mason (1989), High-temperature cation distributions in $\mathrm{Fe}_{3} \mathrm{O}_{4}-\mathrm{MgFe}_{2} \mathrm{O}_{4}-\mathrm{FeAl}_{2} \mathrm{O}_{4}-\mathrm{MgAl}_{2} \mathrm{O}_{4}$ spinels from thermopower and conductivity measurements, Am. Mineral., 74, 339351 .

Nuccio, P. M., and A. Paonita (2000), Investigation of the noble gas solubility in $\mathrm{H}_{2} \mathrm{O}-\mathrm{CO}_{2}$ bearing silicate liquids at moderate pressure: II: The 
extended ionic porosity (EIP) model, Earth Planet. Sci. Lett., 183(3-4), 499-512.

Osborn, E. F. (1959), Role of oxygen pressure in the crystallization and differentiation of basaltic magma, Am. J. Sci., 257, 609-647.

Park, S. K., and M. N. Ducea (2003), Can in situ measurements of mantle electrical conductivity be used to infer properties of partial melts?, J. Geophys. Res., 108(B5), 2270, doi:10.1029/2002JB001899.

Partzsch, G. M., F. R. Schilling, and J. Arndt (2000), The influence of partial melting on the electrical behaviour of crustal rocks: Laboratory examinations, model calculations and geological interpretations, Tectonophysics, 317, 189-203.

Pichavant, M., B. O. Mysen, and R. Macdonald (2002), Source and $\mathrm{H}_{2} \mathrm{O}$ content of high-MgO magmas in island arc settings: An experimental study of a primitive calc-alkaline basalt from St. Vincent, lesser Antilles arc, Geochim. Cosmochim. Acta, 66, 2193-2209.

Pous, J., P. Queralt, J. Ledo, and E. Roca (1999), A high electrical conductive zone at lower crustal depth beneath the Betic Chain (Spain), Earth Planet. Sci. Lett., 167, 35-45.

Presnall, D. C., C. L. Simmons, and H. Poath (1972), Changes in electrical conductivity of a synthetic basalt during melting, J. Geophys. Res., 77, 5665-5672.

Reid, J. E., A. Suzuki, K.-I. Funakoshi, H. Terasaki, B. T. Poe, D. C. Rubie, and E. Ohtani (2003), The viscosity of $\mathrm{CaMgSi}_{2} \mathrm{O}_{6}$ liquid at pressures up to $13 \mathrm{GPa}$, Phys. Earth Planet. Inter., 139, 30, 45-54.

Richet, P. (1984), Viscosity and configurational entropy of silicate melts, Geochim. Cosmochim. Acta, 48, 471-483.

Roberts, J. J., and J. A. Tyburczy (1999), Partial-melt electrical conductivity: Influence of melt composition, J. Geophys. Res., 104, 70557065 .

Scaillet, B., M. Pichavant, and J. Roux (1995), Experimental crystallization of leucogranite magmas, J. Petrol., 36, 663-705.

Scarlato, P., B. T. Poe, C. Freda, and M. Gaeta (2004), High-pressure and high-temperature measurements of electrical conductivity in basaltic rocks from Mount Etna, Sicily, Italy, J. Geophys. Res., 109, B02210, doi:10.1029/2003JB002666.

Schilling, F. R., and G. M. Partzsch (2001), Quantifying partial melt portion in the crust beneath the central Andes and the Tibetan Plateau, Phys. Chem. Earth, Part A, 26, 239-246.

Schilling, F. R., G. M. Partzsch, H. Brase, and G. Schwartz (1997), Partia melting below the magmatic arc in the central Andes deduced from geoelectromagnetic field experiments and laboratory data, Phys. Erath Planet. Inter., 103, 17-31.

Sisson, T. W., and T. L. Grove (1993), Experimental investigations of the role of water in calc-alkaline differentiation and subduction zone magmatism, Contrib. Mineral. Petrol., 113, 143-166.

Toplis, M. J., and M. R. Carroll (1995), An experimental study of the influence of oxygen fugacity on Fe-Ti oxides stability, phase relations, and mineral-melt equilibria in ferro-basaltic systems, J. Petrol., 36, $1137-1170$

Tyburczy, J., and D. K. Fisler (1995), Electrical properties of minerals and melts, in Mineral Physics and Crystallography: A Handbook of Physical Constants, Ref. Shelf, vol. 2, edited by T. J. Ahrens, pp. 185-208, AGU, Washington, D. C

Tyburczy, J., and H. S. Waff (1983), Electrical conductivity of molten basalt and andesite to 25 kilobars pressure: Geophysical significance and implications for the charge transport and melt structure, J. Geophys. Res., 88, 2413-2430.

Tyburczy, J., and H. S. Waff (1985), High pressure electrical conductivity in naturally occurring silicate liquids, in Point Defects in Minerals, Geophysical Monogr. Ser., vol. 31, edited by R. N. Shock, pp. 78-87, AGU, Washington, D. C.

Waff, H. S. (1974), Theoretical considerations of electrical conductivity in a partially molten mantle and implications for geothermometry, J. Geophys. Res., 79, 4003-4010.

Waff, H. S., and D. F. Weill (1975), Electrical conductivity of magmatic liquids: Effects of temperature, oxygen fugacity and composition, Earth Planet. Sci. Lett., 28, 254-260.

Watson, E. B. (1994), Diffusion in volatile-bearing magmas, in Volatiles in Magmas, Rev. Mineral., vol. 30, edited by M. R. Carroll and J. R. Holloway, pp. 371-411, Mineral. Soc. Am., Washington, D. C.

$\mathrm{Wu}, \mathrm{X}$., and Y. Zheng (2003), Compensation effect for electrical conductivity and its applications to estimate oxygen diffusivity in minerals, J. Geophys. Res., 108(B3), 2139, doi:10.1029/2002JB001783.

F. Gaillard, Institut des Sciences de la Terre d'Orleans, UMR 6113 CNRS-Universite d'Orleans, 1A rue de la Ferollerie, F-45071 Orleans Cedex, France. (fabrice.gaillard@cnrs-orleans.fr)

G. I. Marziano, Dipartimento CFTA, Università degli studi di Palermo, I-90123 Palermo, Italy. (giadaim@tiscali.it) 